\title{
PENGARUH BLENDED LEARNING TERHADAP MOTIVASI BELAJAR DAN HASIL BELAJAR SISWA TINGKAT SMK
}

\author{
Sulihin B. Sjukur \\ SMK Negeri 1 Satui Kab. Tanah Bumbu \\ Suli.cept@gmail.com
}

\begin{abstract}
Abstrak: Pengaruh Blended Learning Terhadap Motivasi Belajar dan Hasil Belajar Siswa di Tingkat SMK. Penelitian ini bertujuan untuk: 1) mengetahui perbedaan motivasi belajar dan hasil belajar antara siswa yang diajarkan pembelajaran blended learning dibanding siswa yang diajarkan pembelajaran konvensional, 2) mengetahui peningkatan motivasi belajar dan hasil belajar siswa akibat penerapan pembelajaran blended learning. Jenis penelitian ini quasi experiment. Populasi penelitian adalah sebanyak 62 siswa dilakukan secara random assignment. Teknik pengumpulan data menggunakan tes tertulis dan angket. Data yang diperoleh dianalisis serta diuji dengan statistik parametrik uji $F$ dan uji . Hasilnya sebagai berikut. 1) Terdapat perbedaan motivasi belajar antara siswa yang diajar pembelajaran blended learning dibandingkan siswa yang diajar pembelajaran konvensional dengan nilai sig. 0,012 dengan rata-rata 4,74 dan terdapat perbedaan hasil belajar dengan nilai sig. 0,000 dengan rata-rata 13,39. 2) Ada peningkatan motivasi belajar siswa akibat penerapan pembelajaran blended learning dengan nilai sig. 0,000 rata-rata peningkatan 13,55 dan ada peningkatan hasil belajar siswa dengan nilai sig. 0,000 rata-rata peningkatan 38,23.
\end{abstract}

Kata Kunci: blended learning, LMS, TKJ, motivasi belajar, hasil belajar

\section{THE EFFECTS OF BLENDED LEARNING ON THE LEARNING MOTIVATION AND ACHIEVEMENT STUDENTS LEVEL SMK}

\begin{abstract}
The Effects of Blended Learning on the Learning Motivation and Achievement Students in level SMK. This research is aimed to: 1) find out the difference in learning motivation and learning achievement of the students taught using blended learning compared to those taught using conventional learning, 2) find out the improvement in learning motivation and learning achievement of the students due to blended learning application. The research type used is quasi-experiment research. The population of this research students which comprised of 62 students. To determine a random assignment. The data collection techniques used are written test and questionnaire. The data gathered was then analyzed and tested by using the F-test and t-test parametric statistics. The results are as follows. 1) There is a difference in learning motivation of the students taught using blended learning compared to those taught using conventional learning with the sig. 0.012 with the average 4.74 and there is a difference in learning achievement of the students with the sig 0.000 with the average 13.39.2) there is an improvement in learning motivation of the students due to blended learning application with the sig. 0.000 with the average 13.55 and there is an improvement in learning achievement of the students with the sig. 0.000 with the average 38.23 .
\end{abstract}

Key Words: blended learning, LMS, TKJ, learning otivation, learning achievement 


\section{PENDAHULUAN}

Kementerian Pendidikan dan Kebudayaan sebagai organisasi yang berfungsi mengelola pendidikan di Indonesia menyambut baik perkembangan ICT dengan memasukkan kurikulum yang bernuansa pengenalan teknologi informasi dan komunikasi, terutama di jenjang pendidikan menengah kejuruan yang diorientasikan pada tujuan strategis pembangunan pendidikan menengah kejuruan yang mengacu pada Rencana Strategis Kementerian Pendidikan dan Kebudayaan, yaitu tersedianya dan terjangkaunya layanan pendidikan menengah kejuruan yang bermutu, relevan, dan berkesetaraan di semua provinsi, kabupaten, dan kota.

Salah satu Kebijakan Umum Direktorat Pembinaan SMK Tahun 2011 didasarkan pada hasil evaluasi pelaksanaan program tahun 2010, dan Rancangan Renstra Direktorat Pembinaan SMK Tahun 2010-2014 adalah upaya untuk mencapai sasaran sekurang-kurangnya $70 \%$ SMK melaksanakan e-pembelajaran, emanajemen dan e-layanan.

Respon ini menunjukkan bahwa Kementerian Pendidikan dan Kebudayaan memperhatikan perkembangan teknologi informasi dan komunikasi yang sedang mengalami kemajuan pesat. Kebijakan ini bertujuan agar siswa memiliki bekal kemampuan untuk mengenal, memahami, dan berinteraksi dengan teknologi informasi dan komunikasi, sehingga kelak pada saat lulus tidak buta sama sekali dengan teknologi informasi dan komunikasi yang ada di masyarakat.

Mata pelajaran produktif TKJ merupakan salah satu mata pelajaran wajib bagi siswa SMK baik itu di kelas X atau di kelas XI dan XII yang mengambil Kompetensi Keahlian Teknik Komputer dan Jaringan.

Berdasarkan data hasil nilai pelajaran produktif dan hasil wawancara dengan guru Produktif TKJ di SMK Negeri 1 Satui, masih banyak siswa yang belum mencapai ketuntasan belajar minimal yakni 70, rata-rata dari siswa baru mencapai ketuntasan 67. Selain masih rendahnya ketuntasan belajar, motivasi dan hasil belajar siswa juga masih rendah, dari hasil pengamatan peneliti terlihat masih kurangnya persiapan siswa ketika waktu pelajaran produktif TKJ dimulai di kelas proses pembelajaran sering terlambat karena siswa dengan sengaja mengulur waktu untuk masuk ke ruang komputer. Meskipun setiap siswa sudah mempunyai sumber belajar (buku paket Produktif TKJ), akan tetapi mereka masih saja ada yang lupa membawanya ataupun mereka membawanya tapi hanya dibawa saja, tidak mencoba untuk memahaminya. Jika kondisi tersebut dibiarkan, maka akan menimbulkan dampak yang kurang baik bagi sekolah.

Kurikulum teknologi, banyak dipengaruhi oleh psikologi belajar behavioristik. Salah satu ciri dari teori belajar ini adalah menekankan pola tingkah laku yang bersifat mekanis seperti yang digambarkan dalam teori Stimulus-respons yang dikutip oleh Sanjaya (2010:76). Lebih lanjut dalam pandangannya tentang belajar kurikulum ini memiliki karakteristik sebagai berikut: (a) belajar dipandang sebagai proses respon terhadap rangsangan; (b) belajar diatur berdasarkan langkah-langkah tertentu dengan sejumlah tugas yang harus dipelajari. Secara khusus siswa belajar secara individual, meskipun dalam hal-hal tertentu bisa saja belajar secara kelompok. 
Tabel 1. Hasil Nilai Produktif TKJ Kelas XI TKJ 1 Semester Ganjil TahunPelajaran 2011/2012

\begin{tabular}{ccc}
\hline \hline Nilai & Jumlah Peserta Didik & Presentase ketuntasan tanpa proses remedial \\
\hline \hline$>69$ & 17 & $55 \%$ \\
$<69$ & 14 & $45 \%$ \\
Jumlah & 31 & $100 \%$ \\
\multicolumn{2}{l}{$\begin{array}{l}\text { Sumber : Daftar Nilai Guru TKJ Kelas XI TKJ 1 SMK Negeri } \\
\text { Pelajaran }\end{array}$ Satui Semester Ganjil Tahun } \\
\end{tabular}

Menurut McNeil yang dikutip oleh Sanjaya (2010:76), tujuan kurikulum teknologis ditekankan kepada pencapaian perubahan tingkah laku yang dapat diukur. Oleh karena itu tujuan umum dijabarkan ke dalam tujuan-tujuan khusus. Tujuan-tujuan itu biasanya diambil dari setiap mata pelajaran (disiplin ilmu). Tujuan yang berorientasi kepada tujuan kemasyarakatan jarang digunakan. Semua siswa diharapkan dapat menguasai secara tuntas tujuan pengajaran yang telah ditentukan.

Sanjaya (2011:219) mengatakan ada beberapa bentuk penggunaan komputer sebagai media yang dapat digunakan dalam pembelajaran meliputi: (a) penggunaan Multimedia Presentasi yaitu multimedia presentasi digunakan untuk menjelaskan materimateri yang sifatnya teoritis, digunakan dalam pembelajaran klasikal dengan kelompok besar. Kelebihannya adalah dapat menggabungkan semua unsur seperti teks, video, animasi, gambar, grafik dan suara; (b) CD Multimedia Interaktif yaitu $\mathrm{CD}$ interaktif dapat digunakan pada berbagai jenjang pendidikan dan berbagai bidang studi. Sifat media ini selain interaktif juga bersifat multimedia terdapat unsur-unsur media secara lengkap yang meliputi suara, animasi, video, teks dan grafis; (c) pemanfaatan Internet yaitu pemanfaatan internet sebagai media pembelajaran mengkondisikan siswa untuk belajar secara mandiri. Para siswa dapat mengakses secara online dari berbagai perpustakaan, museum, database, dan mendapatkan sumber primer. Siswa dan guru tidak perlu hadir secara fisik di kelas, karena siswa dapat mempelajari bahan ajar dan mengerjakan tugas-tugas pembelajaran serta ujian dengan cara mengakses jaringan komputer yang telah ditetapkan secara online.

Istilah blended learning pada awalnya digunakan untuk menggambarkan mata pelajaran yang mencoba menggabungkan pembelajaran tatap muka dengan pembelajaran online. Selain blended learning ada istilah lain yang sering digunakan di antaranya blended learning dan hybrid learning. Istilah yang disebutkan tadi mengandung arti yang sama yaitu perpaduan, percampuran atau kombinasi pembelajaran.

Thorne (2003:2) menggambarkan blended learning sebagai

It represents an opportunity to integrate the innovative and technological advances offered by online learning with the interaction and participation offered in the best of traditional learning.

Sedangkan Bersin

mendefinisikan blended learning sebagai:

the combination of different training "media" (technologies, activities, and types of events) to create an optimum training 
program for a specific audience. The term "blended" means that traditional instructor-led training is being supplemented with other electronic formats. In the context of this book, blended learning programs use many different forms of $e$ learning, perhaps complemented with instructor-led training and other live formats.

Berdasarkan pendapat tersebut, Blended learning sebagai kombinasi karakteristik pembelajaran tradisional dan lingkungan pembelajaran elektronik atau Blended learning. menggabungkan aspek Blended learning (format elektronik) seperti pembelajaran berbasis web, streaming video, komunikasi audio synchronous dan asynchronous dengan pembelajaran tradisional "tatap muka".

Proses penyelenggaraan e-learning, dibutuhkan sebuah Learning Management System (LMS), yang berfungsi untuk mengatur tata laksana penyelenggaraan pembelajaran di dalam model e-learning. Sering juga LMS dikenal sebagai CMS (Course Management System), umunya CMS dibangun berbasis web, yang akan berjalan pada sebuah web server dan dapat diakses oleh pesertanya melalui web browser (web client). Server biasanya ditempatkan di universitas/sekolah atau lembaga lainnya, yang dapat diakses darimanapun oleh pesertanya, dengan memanfaatkan koneksi internet.

Motivasi adalah proses internal yang mengaktifkan, menuntun, dan mempertahankan perilaku dari waktu ke waktu. Ada banyak jenis, intensitas, tujuan, dan arah motivasi yang berbeda-beda. Motivasi untuk belajar sangat berperan penting bagi siswa dan guru.

Pembelajaran mandiri, merujuk pada pembelajaran yang berasal dari pemikiran dan perilaku yang dihasilkan sendiri oleh siswa yang secara sistematis diarahkan ke sasaran pembelajaran mereka (Slavin, 2009:115).

Motivasi intrinsik siswa pada umumnya menurun dari sekolah dasar tahun-tahun pertama hingga sekolah menengah. Karena alasan ini sekolah menerapkan berbagai insentif ekstrinsik (extrinsic incentive), yaitu imbalan untuk pembelajaran yang tidak melekat dalam bahan yang sedang dipelajari (Slavin, 2009:130). Imbalan ekstrinsik dapat berkisar dari pujian, nilai, penghargaan, hingga hadiah atau imbalan lain.

Fenomena motivasi intrinsik mencerminkan kecenderungan utama manusia untuk terlibat dalam kegiatan yang menarik perhatian mereka untuk belajar, mengembangkan dan memperluas kapasitas mereka. Motivasi intrinsik yang terkandung setiap kali orang berperilaku untuk kepuasan yang melekat dalam perilaku itu sendiri (Sansone, Harackiewicz, 2000:16)

Pendapat di atas guru seharusnya mencoba membuat segala sesuatu yang mereka ajarkan sedapat mungkin menarik secara instrinsik dan seharusnya menghindari membagikan imbalan material kalau hal itu tidak perlu, tetapi guru seharusnya tidak merasa enggan menggunakan imbalan ekstrinsik apabila hal itu diperlukan.

Para ahli psikologi mendefinisikan motivasi sebagai proses internal yang mengaktifkan, menuntun, dan mempertahankan perilaku dari waktu ke waktu. Dalam bahasa sederhana, motivasi adalah sesuatu yang menyebabkan anda berjalan, membuat anda tetap berjalan, dan menentukan ke mana anda berusaha berjalan (Slavin, 2009:105). 
Hasil belajar merupakan kemampuan yang diperoleh individu setelah proses belajar berlangsung, yang dapat memberikan perubahan tingkah laku baik pengetahuan, pemahaman, sikap dan keterampilan siswa sehingga menjadi lebih baik dari sebelumnya. Sebagaimana yang dikemukakan Hilgard yang dikutip oleh Sanjaya, (2010:228-229)

Learning is process by which an activity originates or changed through training procedures (wether in laboratory or in the natural environment) as distinguished from changes by factors not atributable to training.

Menurut Hilgard, belajar itu adalah proses perubahan melalui kegiatan atau prosedur latihan baik latihan di dalam laboratorium maupun dalam lingkungan alamiah. Pendapat tersebut didukung oleh Sanjaya (2010:229) bahwa hasil belajar adalah suatu proses aktivitas mental seseorang dalam berinteraksi dengan lingkungannya sehingga menghasilkan perubahan tingkah laku yang bersifat positif baik perubahan dalam aspek pengetahuan, sikap, maupun psikomotor. Dikatakan positif, oleh karena perubahan perilaku itu bersifat adanya penambahan dari perilaku sebelumnya yang cenderung menetap (tahan lama dan tidak mudah dilupakan).

Berdasarkan pengertian di atas maka dapat disintesiskan bahwa hasil belajar adalah suatu penilaian akhir dari proses dan pengenalan yang telah dilakukan berulang-ulang serta akan tersimpan dalam jangka waktu lama atau bahkan tidak akan hilang selama-lamanya karena hasil belajar turut serta dalam membentuk pribadi individu yang selalu ingin mencapai hasil yang lebih baik lagi sehingga akan merubah cara berpikir serta menghasilkan perilaku kerja yang lebih baik.

Penelitian yang telah dilakukan oleh Muhamad Ali, Istanto WD, Sigit Y, Muhamad Munir (2011) dari FT UNY dengan judul “ Studi Pemanfaatan e-Learning sebagai Media Pembelajaran Guru dan Siswa SMK di Yogyakarta" dari hasil kesimpulan dikatakan bahwa pembelajaran e-learning memberikan pengaruh yang cukup signifikan pada motivasi belajar guru dan siswa, tetapi untuk hasil belajar dan waktu menyelesaikan pelajaran pengaruhnya belum signifikan.

Berdasarkan kajian teori dan hasil-hasil penelitian yang relevan, maka tujuan penelitian ini adalah: (1) mengetahui perbedaan motivasi belajar antara siswa yang diajarkan pembelajaran blended learning dibanding siswa yang diajarkan pembelajaran konvensional; (2) mengetahui perbedaan hasil belajar antara siswa yang diajarkan pembelajaran blended learning dibanding siswa yang diajarkan pembelajaran konvensional; (3) mengetahui peningkatan motivasi belajar siswa akibat penerapan pembelajaran blended learning; (4) mengetahui peningkatan hasil belajar siswa akibat penerapan pembelajaran blended learning.

Secara umum kerangka pikir dalam penelitian ini dapat diilustrasikan sebagai berikut. 


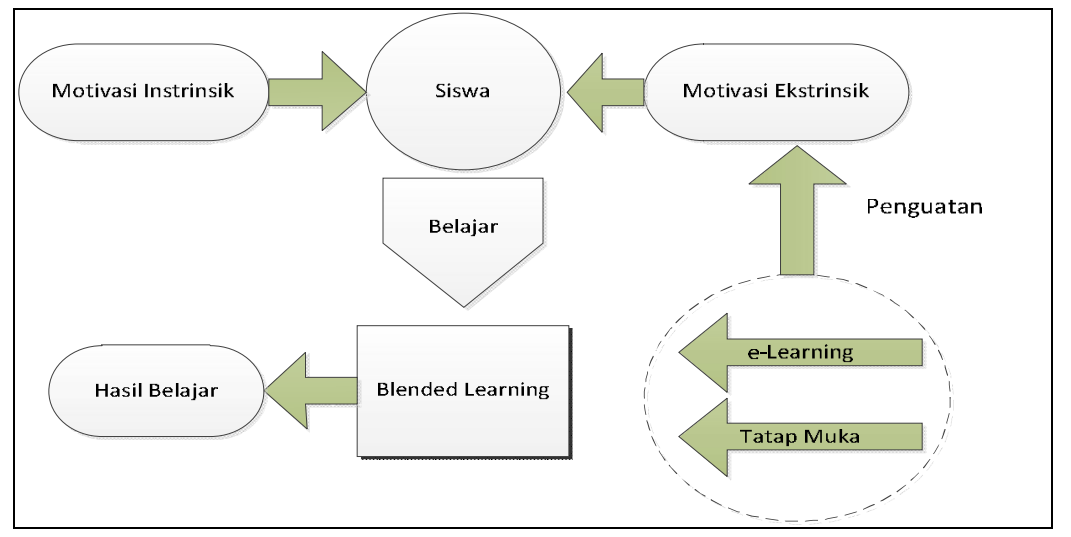

Gambar 1. Kerangka Pikir

\section{METODE}

Penelitian ini termasuk jenis penelitian kuantitatif dengan pendekatan eksperimen semu. Desain yang digunakan adalah "Pretest-Posttest Non Equivalen Control Group Desain".

Populasi dalam penelitian ini adalah seluruh siswa kelas XI Kompetensi Keahlian Teknik Komputer dan Jaringan sebanyak 62 orang yang terdiri dari 2 kelas, yaitu kelas XI TKJ 1 sebanyak 31 siswa dan kelas XI TKJ 2 sebanyak 31 siswa. Pada penelitian ini, menurut Wiersma (1995:284) untuk menentukan kelas eksperimen dan kelas kontrol dilakukan secara random assignment, yaitu pemilihan dilakukan secara acak untuk memilih kelas (groups). Dengan cara undian menggunakan kertas kecil yang dituliskan nama masing-masing kelas. Melalui undian tersebut, diperoleh kelas eksperimen dan kelas kontrol. Hasilnya kelas XI TKJ 1 sebanyak 31 siswa sebagai kelas eksperimen dan kelas XI TKJ 2 sebanyak 31 siswa sebagai kelas kontrol. Kedua kelas tersebut harus berasal dari populasi yang homogen, hal ini ditunjukkan dari hasil homogenitas pretest.

Penelitian ini melibatkan dua variabel, yaitu variabel eksperimen dan variabel terikat.
Adapun sebagai variabel experimen adalah variabel perlakuan untuk kelas eksperimen, yaitu pembelajaran blended learning berbasis LMS, dan variabel perlakuan untuk kelas kontrol yang digunakan sebagai pembanding, yaitu pembelajaran secara konvensional. Sedangkan variabel terikatnya adalah motivasi belajar dan hasil belajar.

Teknik pengumpulan data dalam penelitian ini berupa angket dan tes tertulis yang diberikan kepada siswa sebelum dan sesudah perlakuan pada kedua kelas. Validitas instrumen dalam penelitian ini meliputi validitas rational judgement yakni dengan mengkonsultasikan instrumen kepada para ahli dalam hal ini dosen pembimbing dan dosen lain yang berkompeten dengan cara dimintai pendapatnya tentang instrumen yang telah disusun. Setelah instrumen selesai dikonsultasikan dan telah memenuhi syarat, maka langkah selanjutnya diadakan uji coba di lapangan untuk memperoleh validitas konstruknya. Setelah data didapat dan ditabulasikan, maka pengujian validitas konstruk dilakukan dengan analisis faktor.

Teknik analisis data dilakukan dengan langkah-langkah: (1) pengujian persyaratan analisis dengan uji normalitas dengan 
menggunakan metode Kolmogorov-Smirnov untuk uji homogenitas dilakukan dengan uji levene test, dan (2) uji hipotesis dalam penelitian ini untuk hipotesis 1 dan 2 menggunakan uji $F$ anova untuk hipotesis 3 dan 4 menggunakan paired samples t test.

\section{HASIL PENELITIAN}

Berdasarkan hasil hipotesis 1 menggunakan pada taraf signifikansi 0,05 diperoleh bahwa terdapat perbedaan motivasi belajar antara siswa yang diajarkan pembelajaran blended learning dibandingkan siswa yang diajarkan pembelajaran konvensional. dimana nilai $\mathrm{F}$ hitung sebesar 6,753 lebih besar dari nilai $\mathrm{F}$ tabel sebesar 4,001 dan level signifikansi sebesar (P) 0,012 lebih kecil dari $(\alpha) 0,05$.

Rata-rata skor motivasi belajar kelas eksperimen sebesar 13,55. Rata-rata skor motivasi belajar kelas kontrol sebesar 8,81. Rata-rata skor motivasi belajar sesudah pembelajaran lebih besar dibanding rata-rata skor motivasi belajar sebelum pembelajaran. Perbedaan rata-rata peningkatan skor motivasi belajar antara kelas eksperimen dan kelas kontrol sebesar 4,74.

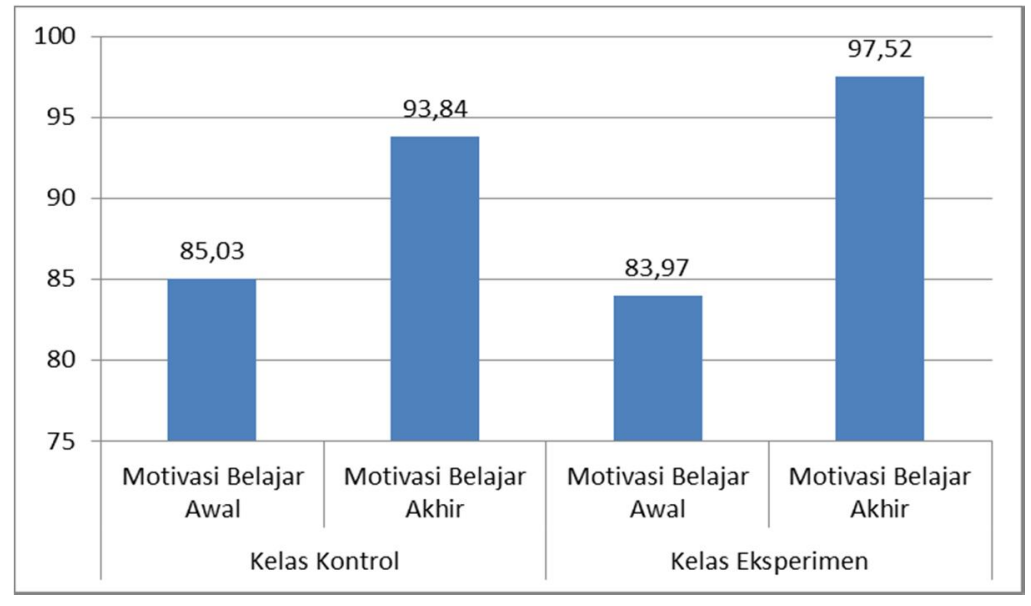

Gambar 2. Perbedaan Rata-Rata Motivasi Belajar Awal dan Akhir pada Kedua Kelas

Berdasarkan hasil hipotesis 2 menggunakan pada taraf signifikansi 0,05 diperoleh bahwa terdapat perbedaan hasil belajar antara siswa yang diajarkan pembelajaran blended learning dibandingkan siswa yang diajarkan pembelajaran konvensional. dimana nilai $\mathrm{F}$ hitung sebesar 26,240 lebih besar dari nilai $F$ tabel sebesar 4,001 dan level signifikansi (P) sebesar $0,000<(\alpha) 0,05$.

Rata-rata skor hasil belajar kelas eksperimen sesudah pembelajaran lebih tinggi dibanding rata-rata skor hasil belajar sebelum pembelajaran. Perbedaan rata-rata skor hasil belajar kelas eksperimen sebesar 38,23, sedangkan perbedaan rata-rata skor hasil belajar kelas kontrol sebesar 24,84 . Perbedaan rata-rata peningkatan skor hasil belajar antara kelas eksperimen dan kelas kontrol sebesar 13,39. Gambaran perbedaan rata-rata peningkatan skor hasil belajar antara kelas eksperimen dan kelas kontrol disajikan pada Gambar berikut ini. 


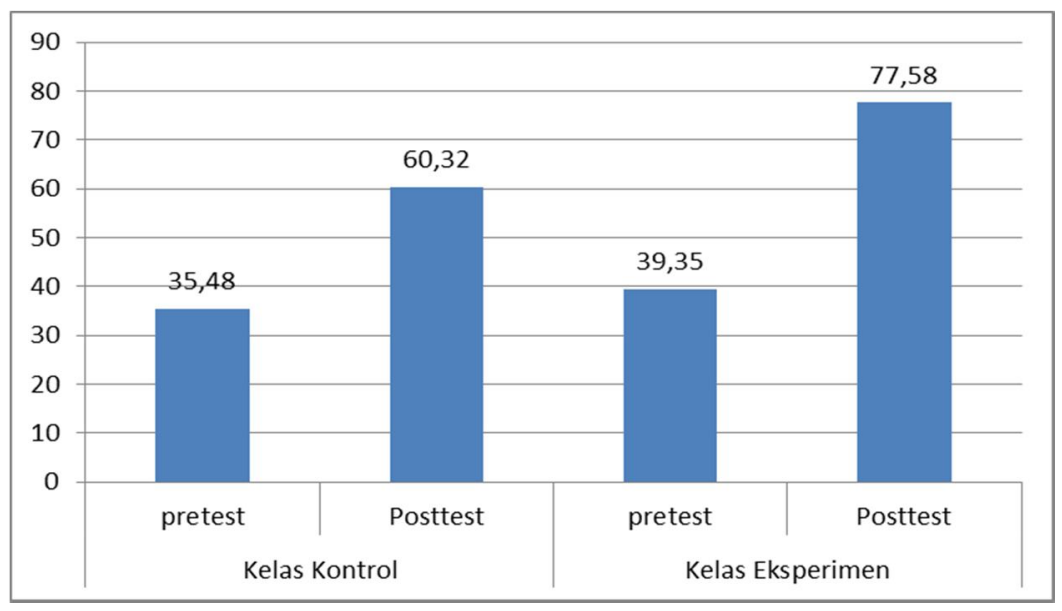

\section{Gambar 3. Perbedaan Rata-Rata Hasil Belajar Sebelum dan Sesudah Pembelajaran} pada Kelas Eksperimen

Berdasarkan hasil hipotesis 3 sebesar 83,97. Kemudian setelah diberi menggunakan pada taraf signifikansi 0,05 pembelajaran dengan memanfaatkan blended diperoleh bahwa ada peningkatan motivasi learning sebanyak lima kali pertemuan, motivasi belajar siswa akibat penerapan pembelajaran belajar diukur lagi dan diperoleh rata-rata blended learning. dimana nilai $\mathrm{t}_{\text {hitung }}$ sebesar 9,406 lebih kecil dari nilai $t_{\text {tabel }}$ sebesar $-1,697$ untuk taraf kesalahan 5\% serta level signifikansi (P) sebesar $0,000<(\alpha) 0,05$. motivasi belajar 97,52 yang artinya ada peningkatan rata-rata sebesar 13,55. Gambaran peningkatan rata-rata motivasi belajar disajikan pada Gambar berikut ini.

Rata-rata skor motivasi belajar yang diukur sebelum pembelajaran blended learning

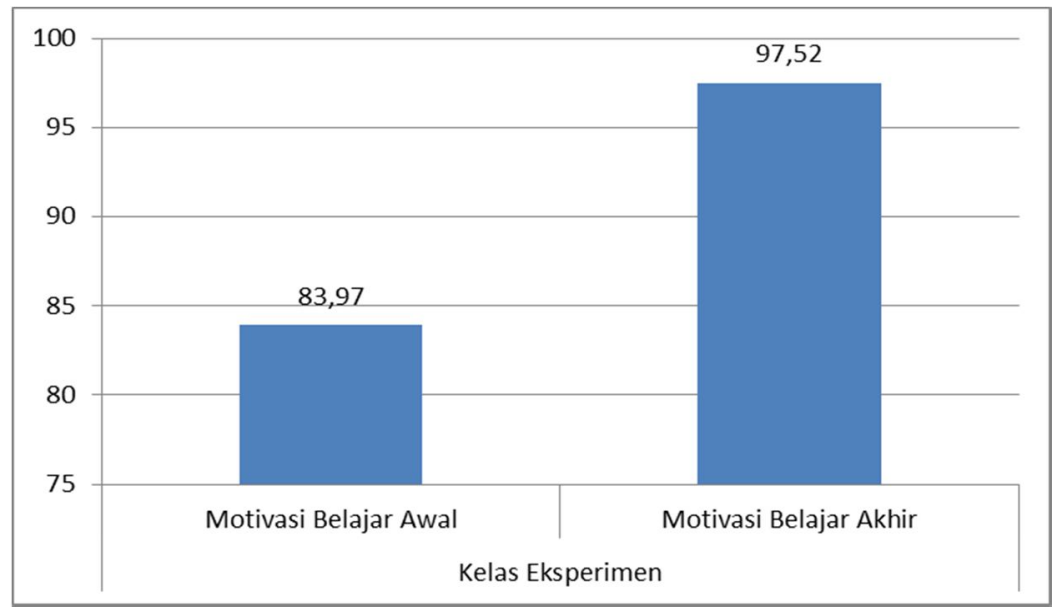

Gambar 4. Rata-Rata Motivasi Belajar Sebelum dan Sesudah Menggunakan Blended Learning 
Berdasarkan hasil hipotesis 4 menggunakan pada taraf signifikansi 0,05 diperoleh bahwa ada peningkatan hasil belajar siswa akibat penerapan pembelajaran blended learning. dimana nilai $\mathrm{t}$ hitung sebesar -19,628 lebih kecil dari nilai $\mathrm{t}_{\text {tabel }}$ sebesar -1,697 untuk taraf kesalahan 5\% serta level signifikansi (P) sebesar $0,000<(\alpha) 0,05$.
Rata-rata skor hasil belajar yang diukur sebelum pembelajaran blended learning sebesar 39,35. Kemudian setelah diberi pembelajaran dengan menerapkan blended learning sebanyak lima kali pertemuan, hasil belajar diukur lagi dan diperoleh rata-rata hasil belajar 77,58 yang artinya ada peningkatan hasil belajar rata-rata sebesar 38,23. Gambaran peningkatan rata-rata hasil belajar disajikan pada Gambar berikut ini.

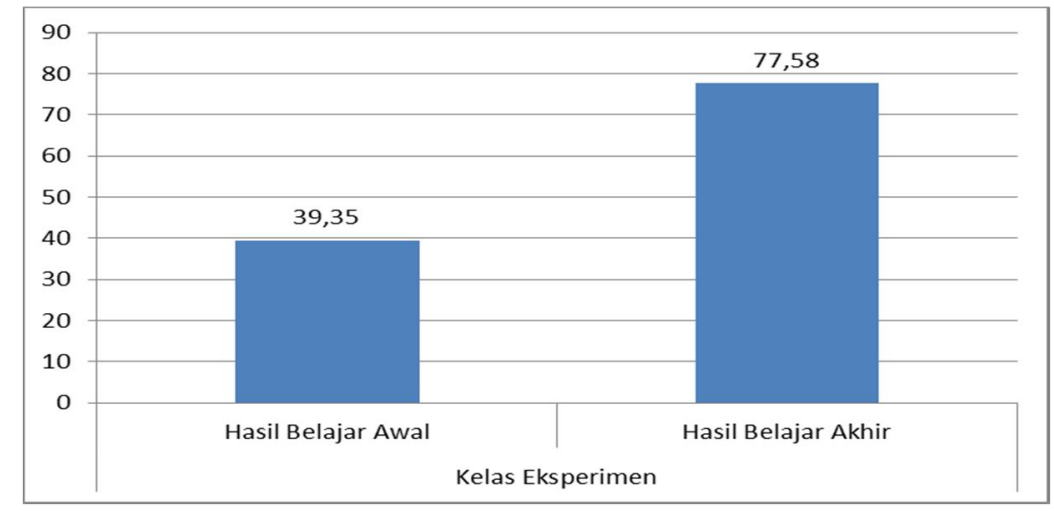

Gambar 5. Rata-Rata Hasil Belajar Sebelum dan Sesudah Menggunakan Blended Learning

\section{KESIMPULAN DAN SARAN}

Berdasarkan hasil penelitian yang telah dikemukakan pada bab sebelumnya, dapat disimpulkan sebagai berikut: (1) terdapat perbedaan motivasi belajar antara siswa yang diajarkan pembelajaran blended learning dibandingkan siswa yang diajarkan pembelajaran konvensional; (2) terdapat perbedaan hasil belajar antara siswa yang diajarkan pembelajaran blended learning dibandingkan siswa yang diajarkan pembelajaran konvensional; (3) ada peningkatan motivasi belajar siswa akibat penerapan pembelajaran blended learning; (4) ada peningkatan hasil belajar siswa akibat penerapan pembelajaran blended learning.
Berdasarkan simpulan di atas, peneliti memberikan saran untuk berbagai pihak yang berkepentingan terhadap penelitian ini, yaitu: (1) para guru mata diklat produktif teknik komputer dan jaringan maupun guru adaptif dan normatif dapat menerapkan pembelajaran blended learning pada mata diklat yang di ampu karena terbukti terdapat perbedaan motivasi belajar dan hasil belajar antara siswa yang diajarkan pembelajaran blended learning dibandingkan siswa yang diajarkan pembelajaran konvensional; (2) guru produktif TKJ maupun guru adaptif dan normatif dapat menerapkan pembelajaran blended learning pada mata pelajaran yang di ampu karena terbukti ada peningkatan motivasi belajar siswa dan peningkatan hasil belajar siswa. 


\section{DAFTAR PUSTAKA}

Bersin, J. 2004. The blended learning book: Best practices, proven methodologies, and lessons learned. San Francisco: Pfeiffer Publishing.

Brophy, J. 2010. Motivating students to learn ( $3^{\text {rd }}$ ed.). New York: Routledge.

Cepi Riyana. 2011. Teknologi informasi dan komunikasi dalam pembelajaran: Blended learning. Artikel tik, 21-24. 13 Oktober 2011, dari http://kurtek.upi.edu/tik/content/blend ed.pdf.

Cole, J., \& Foster, H. 2008. Using moodle $\left(2^{\text {nd }}\right.$ ed.). California: O'Reilly Media, Inc.

Creswell, J.W. 2011. Research design: Pendekatan kualitatif, kuantitatif, dan mixed, edisi ketiga. (Terjemahan Achmad Fawaid). Yogyakarta: Pustaka Pelajar. (Buku asli diterbitkan tahun 2009)

Daniels, H. 2005. An introduction to vygotsky, $\left(2^{\text {nd }}\right.$ ed.). New York: Routledge.

Daryanto. 2010. Media pembelajaran peranannya sangat penting dalam mencapai tujuan pembelajaran. Yogyakarta: Gava Media.

Depdiknas. 2005. Undang-Undang RI. Nomor 14 Tahun 2005 tentang Guru dan Dosen.

Depdiknas. 2007. Peraturan Menteri Pendidikan Nasional RI. Nomor 16 Tahun 2007 tentang Standar Kualifikasi Akademik dan Kompetensi Guru.

Depdiknas. 2008. SK Direktur Jenderal Manajemen Pendidikan Dasar dan Menengah Departemen Pendidikan Nasional Nomor: 251/C/KEP/MN/2008, tentang Spektrum Keahlian Pendidikan Menengah Kejuruan.

Dit.PSMK. 2009. Standar kompetensi dan kompetensi dasar (SKKD) teknik komputer dan informatika. Diambil pada tanggal 19 Oktober 2011, dari ftp://124.81.109.86/Pembelajaran/Kuri kulum/SKKD/SMK/SKKD/.

Dit.PSMK. Dit.Men 2011. Garis-garis besar program pembinaan smk tahun 2011. Draft rencana strategis direktorat pembinaan smk tahun 2010 - 2014 .

Frey, B.A., \& Sutton, J.M. 2010. A model for developing multimedia learning projects.
Merlot journal of online learning and teaching. Vol. 6, no. 2, june, 491. University of Pittsburgh. Pittsburgh. 13 Oktober 2011, dari http:// jolt.merlot.org/vol6no2/frey_0610.pdf

Hasibuan, Z.A. (9 - 11 September, 2006). Integrasi aspek pedagogi dan teknologi dalam e-learning studi kasus: Pengembangan e-learning di fakultas ilmu komputer, UI. Makalah disajikan dalam Seminar Teknologi Pendidikan ke-19, Lengkawi, Kedah, Malaysia. 13 Oktober 2011, dari http://kambing.ui.ac.id/onnopurbo/libr ary/library-ref-ind/ref-ind2/ application/education/Integrasi Aspek Pedagogi dan Teknologi v3.doc

Heinze, A. 2008. Blended learning: An interpretive action research study. $\mathrm{PhD}$ Thesis, tidak diterbitkan, University of Salford, Manchester. 13 Oktober 2011, dari http://usir.salford.ac.uk/1653/1/ Heinze 2008 blended elearning.pdf

Heinze, A., \& Procter, C. (13-14 September, 2004). Reflections on the use of blended learning. Education in a changing environment conference proceedings: Education development unit. University of Salford, Manchester. 13 Oktober 2011, dari http://www.ece.salford.ac.uk/ proceedings/papers/ah_04.rtf

Herman Dwi Surjono. 2011. Membangun course e-learning berbasis moodle. Yogyakarta: UNY Press.

Johnson, R.L., Penny, J.A., \& Gordon, B. 2009. Assessing performance: Designing, scoring, and validating performance. New York: The Guilford Press.

Jonathan Sarwono. 2009. Statistik itu mudah: Panduan lengkap untuk belajar komputansi statistik menggunakan SPSS 16. Yogyakarta: Penerbit ANDI.

Maslow, A. H. 1954. Motivation and personality. New York: Harper \& Row, Publishers, Inc.

Mayer, R.E. 2009. Multimedia learning: Prinsipprinsip dan aplikasi. (Terjemahan Baroto Tavip Indrojarwo) Yogyakarta: Pustaka Pelajar. (Buku asli diterbitkan tahun 1999) 
Mihai, A., \& Christova, A. 2011. Teaching european studies: A blended learning approach. Institute for european studies (IES) - Vrije Universiteit Brussel (VUB). Belgium. International journal of emerging technologies in learning (iJET). Vol. 6, No. 4, 1-2. 10 Oktober 2011, dari http://euce.org/eusa/2011/papers/9d_2 mihai.pdf.

Munir, 2008. Kurikulum berbasis teknologi informasi dan komunikasi. Bandung: SPS Universitas Pendidikan Indonesia.

Riduwan. 2010. Belajar mudah penelitian untuk guru-karyawan dan peneliti pemula. Bandung: Alfabeta.

Sansone, C., Judith, M., \& Harackiewicz. (2000). Intrinsic and extrinsic motivation: The search for optimal motivation and performance. San Diego: Academic Press.

Siahaan, S. 2008. Mengapa harus menggunakan e-learning dalam kegiatan pembelajaran?. Jurnal Teknodik. Vol. 12 No. 1 Juni 2008, 43-54. Jakarta: Departemen pendidikan Nasional Pusat Teknologi Komunikasi dan Informasi Pendidikan.

Singgih Santoso. 2012. Aplikasi SPSS pada statistik parametrik. Jakarta: PT Elex Media Komputindo.

Siregar, S. 2011. Statistika deskriptif untuk penelitian dilengkapi perhitungan manual dan aplikasi SPSS Versi 17. Jakarta : Rajawali Pers.

Slavin, R.E. 2008. Psikologi pendidikan teori dan praktik, edisi kedelapan, Jilid pertama. (Terjemahan Marianto Samosir). Jakarta: PT Index (Buku asli diterbitkan tahun 2006)

Slavin, R.E. 2009. Psikologi pendidikan teori dan praktik, edisi kedelapan, Jilid kedua. (Terjemahan Marianto Samosir). Jakarta: PT Index (Buku asli diterbitkan tahun 2006)

Sugiyono. 2011. Statistika untuk penelitian. Bandung : Alfabeta.
Suharsimi Arikunto. 2010. Prosedur penelitian: Suatu pendekatan praktik. Jakarta: Rineka Cipta.

Syaad Patmanthara. 2006. Pemanfaatan teknologi informasi dan komunikasi untuk pengembangan pembelajaran melalui web sekolah. Jurnal Teknodik No.19/x/Teknodik/Des/2006, 56-67. Jakarta: Departemen pendidikan Nasional Pusat Teknologi Komunikasi dan Informasi Pendidikan.

Thorne, K. 2003. Blended learning : How to integrate online and traditional learning. London: Kogan Page Publishers.

Wahyudi. 2011. Naik 13 juta, pengguna internet indonesia 55 juta orang. 1 November 2011, dari http://tekno.kompas.com/read/ 2011/ $10 /$ $28 /$ 16534635/Naik.13.Juta..Pengguna.Inte rnet.Indonesia.55.Juta.Orang).

Wasis Dwiyogo. 8 Mei 2012. Blended Learning. Pembelajaran berbasis blended learning. $13 \quad$ Mei 2012 dari http://id.wikibooks.org/_wiki/ Pembelajaran_Berbasis_Blended_Lear ning.

Wiersma, W. 1995. Research methods in education: An introduction (6 $6^{\text {th }}$ ed.). Boston: Allyn and Bacon.

Wikipedia. (10 Mei 2012). program pembelajaran elektronik. Learning management system. 13 Mei 2012 dari http:// http://id.wikipedia.org/ wiki/ Learning_Management_System.

Wina Sanjaya. 2010. Kurikulum dan pembelajaran: Teori dan praktik pengembangan kurikulum tingkat satuan pendidikan (KTSP). Jakarta: Kencana Prenada Media Group.

Wina Sanjaya. 2011. Perencanaan dan desain sistem pembelajaran. Jakarta: Kencana Prenada Media Group. 